UDC 37(477:247)

Mykola CHUMAK, Candidate of Pedagogic Sciences, Associate Professor of The Department of Theories and Methods of Teaching Physics and Astronomy of the National Pedagogical Dragomanov University

\title{
THE DEVELOPMENT OF TECHNICAL EDUCATION OF NADDNIPRYANSHCHYNA IN THE FIRST TWENTY YEARS OF THE XX CENTURY
}

\author{
Микола ЧУМАК, доиент кафедри теорії та методики \\ навчання фізики та астрономії Начіонального \\ педагогічного університету імені М. П. Драгоманова
}

\section{РОЗВИТОК ТЕХНІЧНОЇ ОСВІТИ НАДДНІПРЯНЩИНИ В ПЕРШЕ ДВАДЦЯТИЛІТТЯ ХХ СТОЛІТТЯ}

The subject of the article is focused on the analysis of the peculiarities of the development of technical education in the areas of the Dnieper region under the influence of historical milestones of the first half of the twentieth century.

The basis of the influence of scientific and technological progress of the European states on the trajectory of development of the national education of the studied period is systematized.

It was noted that historical events in the territory of Ukraine that affected all spheres of society's life (in particular, socio-economic, political, cultural and educational) had a significant influence on socio-cultural "crystallization" of domestic technical education.

On the basis of the author's generalizations, the socio-cultural progress of the educational branch was reflected, which was possible due to: the progressiveness of educational initiatives, the diversification of didactic tools, the growing authority of progressive and intelligent circles in the international arena, and the high effectiveness of research developments.

Key words: development, Naddnipryanshchyna, technical education, socio-cultural conditions.

Анотація. Тематику статті концентровано на аналізі особливостей розвитку технічної освіти на теренах Наддніпрянщини під впливом історичних віх першої половини XX століття.

(C) М. Чумак
Систематизовано основоположність впливу науково-технічного прогресу європейських держав на траєкторію розвитку вітчизняної освіти досліджуваного періоду.

Зауважено, що значний вплив на соціокультурну "кристалізацію" вітчизняної технічної освіти мали історичні події на території України, які торкалися усіх сфер життєдіяльності суспільства (зокрема, соціально-економічні, політичні та культурноосвітні).

На основі авторських узагальнень відрефлексовано соціокультурний поступ освітньої галузі, що вможливився завдяки: прогресивності просвітницьких ініціатив, урізноманітненню дидактичного інструментарію, зростанню авторитетності прогресивно-інтелігентних кіл на міжнародній арені, високій результативності дослідних починів.

Ключові слова: розвиток, Наддніпрянщина, технічна освіта, соціокультурні умови.

Мета: проаналізувати продуктивність розвитку технічної освіти Наддніпрянщини під впливом мінливості історичних реалій першої половини XX століття.

Articulation of the issue in general terms. A number of historical vicissitudes that affected the native education in the twentieth century were characterized by the combined variability of liberal and conservative reforms. A fleeting reform led to an inertial blow to the educational industry, which "felt" itself responsible for the practical and industrial progress of our country in accordance with the European progress of the period under the study.

The advancing character of industrial progress has actualized the opening of an integrated network of higher educational institutions of the technical profile on the domestic territory, which were concentrated in three regions of the country - Kharkiv region, Kyiv region and Ekaterinoslav region. The selection of such a regional trio was not accidental, since it was based on the existing base of natural resources and personnel potential of the mentioned administrative-territorial units.

The relevance of the retrospective analysis of the studied issues in the current conditions is dictated by one of the fundamental tasks of the New Ukrainian School - the need for the reform of technical education, the experience of its building today is a valuable asset for future generations.

Analysis of recent researches and publications. Some research areas that are tangent to the chosen problem are found in copyright works of $\mathrm{V}$. Andrushchenko, O. Kuriy, K. Krasnolutskyi, V. Syrotyuk, T. Dudka, L. Pshenychna, M. Chumak and others. However, the issue of technical education development needs to be further refined, especially, taking into account the challenges of the New Ukrainian School and the basic needs for building a new educational paradigm.

In accordance with the stated goal, the following research tasks are 
identified:

- to analyze the state of the problem being investigated;

- to follow the peculiarities of the development of the pedagogical theory and practice of the investigated historical epoch;

- to popularize the national historical and pedagogical experience.

The research tools for the study were biographical, chronological and content, incremental, historical, pedagogical and comparative methods.

Presentation of the main research material. At the beginning of the twentieth century, the territory of the Dnieper was marked by the crystallization of valuable educational projects based on the local technical institutes of higher education, which was generally produced by the dominance of pedagogical skills of representatives of the teaching staff of domestic higher schools. The emergence of each new project was not left out of the attention of the domestic and world community, since it contained the features of innovation and progressiveness based on the existing socio-cultural realities.

Ukrainian researcher G. Alterzon in his work "On the History of Technical Education in Ukraine" noted that even before the opening of the abovementioned profile higher schools on the territory of the Naddnipryanshchyna, technical knowledge was flooded as "rivers" of informal educational initiatives in these areas [2]. The source data show that, starting from the 1830 's, profile representatives of the teaching staff of the University of St. Volodymyr spent at least a couple of hours every week giving open lectures for a nonindifferent target audience. As part of the personal review, the following representatives of the university are worth mentioning, such as: chemists Ignatius Fonberg (founder of the chemistry laboratory) and Grigory Chugaevich (co-initiator of educational projects in the territory of Kyiv region); mathematician Matviy Tyhomatskyi (a famous connoisseur of higher algebra) [2].

Comparing the functionality of the key tasks of disseminating technical knowledge in domestic terrains, emphasized that representatives of classical universities, unlike the representatives of technical higher education, pursued the implementation of potentially different socio-cultural tasks. The first ones - drew attention to the continuous observance of the educational goals of the classical university, based on the unequivocal observance of the existing charters and curricula. The second ones - worked on the formation of a favorable educational climate for the growth of highly skilled personnel who were able to support the industrial development of the region and the country as a whole.

In fact, before the revolutionary events of 1917, there were three higher educational institutions of the technical profile on pro-Ukrainian territories, which were maintained at the expense of state financing. The mentioned educational concentrators were located in Slobozhanshchyna (Kharkiv), central territories (Kyiv) and Ekaterinoslavschyna (modern city of Dnipro). It is clear that the distribution of the educational and technical effects of this unsurpassed trio on the Naddnipryanshchyna and the proUkrainian lands in general was quite significant, even on the basis of separate statistical data. In particular, on the pages of the manuscript "Somewhat about the past, the recent past and the present of Ukrainian economy," the researcher stressed that already in the first decade of the XX century the domestic territory increased the industrial potential by 2.5 times, which was the result of the educational policy of the time - to send abroad for training in higher technical schools the most talented graduates of educational institutions, accompanied by a national professor [16].

Judging by the urgent production needs and the government's loyal policy on the necessity of multiplying the domestic personnel reserve, the trajectory of the potential traineeship path was constructed conditionally. It should be noted that we did not accidentally use the definition of "trajectory" and "route", since in Europe the development of higher technical schools started from the last century and continued to actively unfold in the continuation of the studied period. Proceeding from the fact that the development of the physical and mathematical direction of the domestic higher technical schools was closely intertwined with Germany, we consider it expedient to continue the research in the same geopolitical direction. This is mainly due to the fact that the level of branch cooperation of profile specialists, as well as in previous periods of historical development, continued to grow stronger and each year brought even more visible fruits.

Before the onset of the first decade of the twentieth century there were eleven higher technical schools in the German territory: "... Munich, Berlin, Dresden, Hanover, Stuttgart, Brescia, Aachen, Braunschweig, Karlsruhe, Darmstadt ..." and Danzig [21, p. 7$]$.

The materials of the source study base showed that, on the basis of each of the above-mentioned higher schools of Germany, an independent branch of mechanics functioned practically on the basis of the high authority and popularity of physics in scientific circles in the world [21]. Similarly to the Central European country, mechanics in Ukraine also remained one of the favorite sections of physics, as evidenced by materials from relevant literary sources $[1 ; 3 ; 24 ; 4 ; 20 ; 25]$.

Another common features of the German and domestic higher technical schools of the study period were as follows:

- the interest in the advanced development of the electrotechnical direction of only certain educational concentrators (in pro-Ukrainian territories - in "...Lviv, Kharkov ... In Kiev ... "; German - in "...Karlsruhe, Darmstadt "until 1915 inclusive) [26, p. $33 ; 21$, p. 8];

- the development of the mining and educational trend in those regions of the country, in which there were significant reserves of the relevant resource potential (in Ukraine Ekaterinoslav, and abroad - Aachen) [18; 21];

y the organization of "repetitive courses", the task of which was to provide with important information in a concise form that had a narrow profile and deeply practical filling (Kyiv, Munich, Dresden, Stuttgart, etc.) [6; $21]$.

Summing up the analysis of the above-mentioned common features, it becomes clear that, in fact, in the last position of "preparatory courses", proUkrainian higher technical schools were somewhat behind the German branch of network of such educational centers.

Among the list of profile educational concentrates, Kharkiv Technological Institute had the prominent level of progressiveness. The following number of reasons contributed to socio-cultural 
crystallization of the narrow-profile educational pearl of Slobozhanshchyna:

a) the foundation of the first classical university on the territory of Naddnipryanshchyna (Kharkiv University, 1804);

b) a significant indicator of a qualified foreign intelligentsia in the domestic faculty;

c) the development of a long-term project plan for industrial education by a profile physicist in the field of mechanics - I. Vyshnegradsky, centered on the reorientation of the theoretical basis of the content of training for practical and industrial purposes;

d) the rich fuel and resource potential of the province;

e) establishment of close trade and cooperative relations within a number of imperial regions, which actualized the consequences of the liberal policy of the last ministry in relation to subordinate educational structures: "... this is a wilderness in a closed atmosphere ... where progressive social elements intended to get..." [22, $p$. 382].

It should be noted that intensive physicalization was observed in Kharkiv Institute of Technology of the first quarter of the twentieth century (the priority of disciplines of physical content), which is confirmed by the number of disciplines that were taught during the studied period (see Fig. 1).

Fig. 1 showed that the high level of practical orientation of the profile of individual educational disciplines, in particular, the physical-mathematical cycle - General physics, Theoretical mechanics, Applied mechanics, Theory of machine building (Fig. 1) [13; 15].

A fundamental contribution to the pages of the epistolary heritage of the Institute of Manuscripts of the Vernadsky National Library of Ukraine [27, p. 188; 11].

On the pages of O. Ivanov's work "The High School of the Russian Empire at the beginning of the 20th century," the author clearly distinguished between "polytechnization" and "technologisation" of the high school [22, p. 267]. The researcher stressed that the first version was endorsed by scholars, patrons and local production units, and the latter - mostly by production units only [22]. Considering the last thesis as a quite "grounded" to domestic terrain, it should be noted that Kharkiv actively began to implement the practical tasks of technical education, and Kyiv region focused on the implementation of the reality of polytechnic and educational



Fig. 1. Practical orientation of the profile of individual educational disciplines of the Kharkov Institute of Technology (HTI) in the first quarter of the twentieth century [13; 15]

development of productive forces - an indicator of the development of education in different regions of the country;

f) transfer of the institution to direct subordination to the Ministry of Finance on the eve of the twentieth century [14].

In particular, the content of the last paragraph should be detailed, as it envisaged the transition from strictly regulated interference to the progressive development of the educational institution of the Ministry of Education to the more liberal leadership positions of the Ministry of Finance. In this aspect, it is worth referring to the autobiographical essays of the pro-Soviet teacher B. Raykov, who described the development of the Kharkiv Institute of Technology was made by the progressive physicist, specialist in mechanic physics who was recognized and respected by the intelligent circles of Europe - O. Lyapunov. The mentioned historical-pedagogical person was crowned with immense glory due to scientifically grounded decoration "...the theory of stability of equilibrium and motion of mechanical systems..." and unsurpassed conducting of classes in the mentioned alma mater [27, p. 188]. The teacher Lyapunov is considered to be one of the founders of "... a Slobozhansky profile school of mechanics...", which is testified by the approval of the wellknown in Europe Ukrainian researcher D. Grave, found by the author on the ideology. The active patronage support for the Kyiv educational concentre was given by the figures known in the history of pedagogy - representatives of the Tereshchenko family, who financed many educational projects in the capital (in particular, the opening of an ethnographic museum in the $70 \mathrm{~s}$ of the 19th century).

H. DeMetz expressed his personal impression of the course of a series of historical vicissitudes related to the background of the opening of polytechnic profile high school in the capital. According to a well-known domestic physicist, the head of the Kyiv branch of the Russian Technical Society, the question of the Kyiv Polytechnic was rather debatable, as it generated a flurry of sharp debate 
between scientific, pedagogical and entrepreneurial circles [23]. Local intellectuals emphasized the rationalization of funding for highskilled human resource training, taking into account pro-European requirements, while the entrepreneurial community emphasized the use of minimal resources for the training of technical staff, which would further maximize profits [23]. As we see, source-study materials confirmed the various positions of interested circles in the opening of a new profile educational center in the territory of Kyiv region [23]. Highly-educated elite, trying to take into account intercivilizational and educational experience, argued the incompetence of entrepreneurial circles in relation to reflected in the triple factuality:

a) high idea of "...perfect type ..." of the higher technical school polytechnic foundation;

b) the efficiency of the effective development of higher education through the establishment of close cooperation between classical universities and polytechnics;

c) the compromise of technical faculties opening on the basis of the classical universities (in particular, in the absence of a favorable economic climate for the establishment of an independent polytechnic higher educational establishment) $[8, p .466$; 9, p. 25-31].

Proceeding from the provisions of D. Mendeleev's educational concept, it becomes clear that the world-famous studied period became so significant that just the variation of approaches to the organization of higher education of technical profile was its bright example. The fact is that the "zealots" of the profile departments relied on this type of educational experience:

- Belgian - S. Witte, L. Byrpichev and others.;

- German - I. Vyshnegradsky, H. DeMetz and others.;

- mixed (Belgian-German) - D. Mendeleev and others $[4 ; 5 ; 14]$.

On the domestic territory, the socalled "German" model, which was used as a basis for the structural and organizational project of the Polytechnic Higher School in Kyiv, became quite "successful" (see Fig. 2) [7; 21].

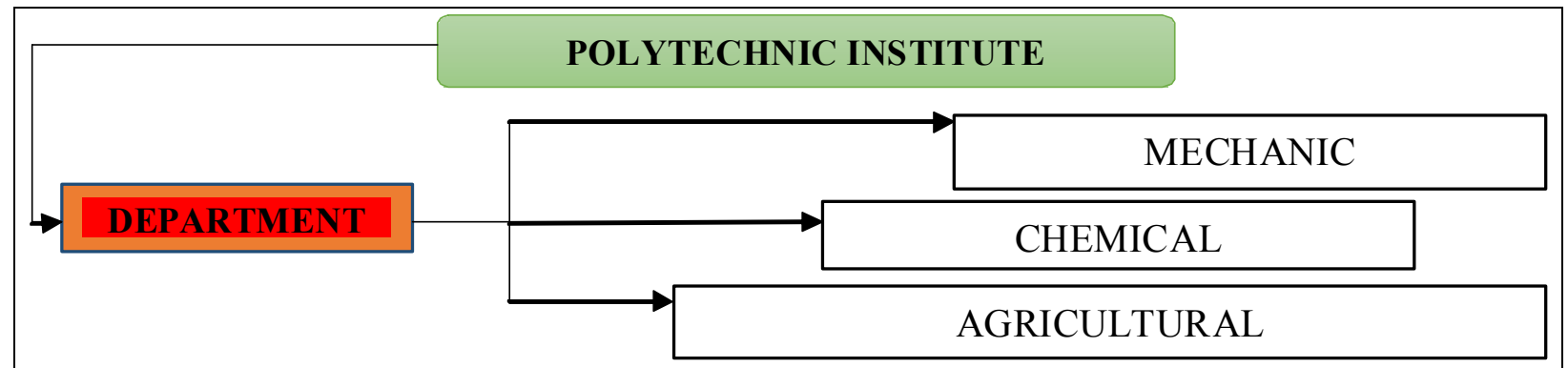

Fig. 2. Layout of the structural and organizational project of the Moscow Polytechnic Institute (on materials of $\mathrm{H}$. DeMetz) [7; 21]

the issue of establishing a qualitative educational process in a context of tight resource conservation [23]. The position of the scientific and pedagogical intelligentsia was supported by the indifferent conscious public, part of which was involved in this process as patrons and initiative ascetics.

The initiative to open a polytechnic high school in Kyiv, and not a technical one, was initiated by the representatives of the profile "Commission on the issues of higher technical education institutions", which in particular was presented by the representative of the Richelieu Lyceum - D. Mendeleiev. Based on many years of experience in visiting foreign higher schools, Dmytro Ivanovich was trying to develop a profile concept that would be promising for the further historical and pedagogical development of our state [12]. Due to the depth of his own pedagogical experience, Mendeleev himself managed to achieve the desired conceptual success, which was teacher was interested in the opening of the domestic network of polytechnic establishments and, at the same time, did not exclude the possibility of opening profile departments at classical universities [9]. Obviously, such a conceptual position of Dmitry Ivanovich can be explained from the socio-economic conditions of that time, which left much to be desired, and therefore the position on the profile departments in this key was sufficiently justified due to the strict regime of state funds saving.

Nevertheless, the photographer in the field of teaching physics at school - G. DeMetz did not support the ideology of interested persons in the opening of profile faculties at existing universities, and yet, according to the source documents, they had the right to open a polytechnic in Kiev [10] with their soul mates.

It should be emphasized that the level of progressiveness of pedagogical skill, multiplied by the national experience of mastering the best world educational traditions, during the
Fig. 2 testifies to the high degree of progressiveness of the structural and organizational project of the Polytechnic High School, represented by $\mathrm{H}$. DeMetz which included an unsurpassed trio of narrow-profile divisions - mechanical, chemical and agricultural (land-economic) [7]. In particular, the presence of the of the first structural element can be explained by two main points: first, the high degree of mechanics popularity at that time; and secondly, the range of scientific and educational interests of $H$. DeMetz in the particular section of physics [7]. It should be noted that just in such content of the structural and organizational layout, the project of $\mathrm{H}$. DeMetz received a number of positive reviews and was taken as a basis for the opening of a new educational institution (Fig. 2). Thus, in the historical context, the profile institute of Kiev became the second "polytechnic" in pro-Ukrainian territories after the Lviv educational concentre.

During the investigated period, the 
development of the applied mechanics issue - construction, became significant. It was possible thanks to the fundamental activities of the representatives of the Moscow Polytechnic Institute [20]. A narrowly thematic study touched on the following problems: "...the resistance of materials ... the theory of strength ... statics of structures..." [17, p. 85-128]. They were quite promising during the period under the study and formed the basis for further development of the national higher technical profile education.

Conclusions and perspectives of further research. Summarizing the stated above, it should be noted that the development of domestic polytechnic education in Ukraine was rather uneven. This situation was dictated by the influence of external factors (in particular, international and domestic policies, economic and industrial development) and internal (in particular, the territorial and resource potential, the presence of classical universities in the region) factors. The total factor impact was quite significant due to the socio-cultural demand of the Ukrainian lands of the studied period and high-productivity personnel potential of domestic higher schools representatives.

The further implementation of personalized research, tangent to the development of domestic education in different regions of Ukraine during the $\mathrm{XX}$ century seems to be perspective.

\section{ЛІТЕРАТУРА}

1. Академик Д. М. Синцов. Учён. зап. Харьк. ун-та. 1948. Т. 24: Записки НИИ математики и механики и Харьковского математического общества. T. 19. C. 5-12.

2. Альтерзон Г. С. До історії технічної освіти на Україні. Нариси 3 історії техніки і природознавства [відп. ред. К. К. Хрєнов]. Київ : вид-во АН УРСР, 1962. Вип. 1. С. 92-96.

3. Боголюбов А. Н. Классическая механика и техника XVII-XIX вв. // Механика и ичиилизация XVII-XIX вв.: сб. ст. ; под. ред. А. Т. Григорьяна, Б. Г. Кузнецова. Москва : Наука, 1979. С. 68-110.

4. Бунге Н. А. К вопросу о высшем техническом образовании. Киев, 1897. Ч. 1.12 с.

5. Бунге Н. А. К вопросу о высшем техническом образовании. Киев, 1897. Ч. II. 9 с.
6. Бюллетени Киевского Политехнического Общества Инженеров и Агрономов. Киев : Тип. А. М. Пономарева п. у. И. И. Врублевского, 1914. № 2. I-II, 1-24, I-XIV c.

7. Де-Метц Г. Г. Физические институты и мастерские физических приборов за границею: извлеч. из журн. "Инженер" за 1899 г. Киев : Лито-тип. товарищ. И. Н. Кушнерев и К., в Москве, КО, 1900. 66 с.

8. Драгоманов М. П. Листи на Наддніпрянську Україну. Літературно-публічистичні праці. Київ, 1970. T. I. C. 466.

9. Журнал Общего Собрания Императорского Русского Технического Общества 31-го января 1898 года. Записки Императорского Русского Технического Общества. Деятельность о-ва. СПб.: Тип. Импер. АН, 1898. № 4. С. $25-31$.

10. Иллюстрированный сборник материалов к истории возникновения Киевского Политехнического Института. Памяти Виктора Львовича Кирпичева посвящает Киевское Политехническое Общество Инженеров и Агрономов. Киев : Тип. Т-ва И. Н. Кушнерев и К을 1914. 143 с.

11. ІР НБУВ. Ф 41. Од. зб. 16511665. Арк. 25. Граве Д. А.-Букрееву Б. Я. Письма 27 февр. 1901. 22 декабря 1935 г.

12. Історія Одеського університету (1865-2000): Наукове видання / головний редактор В. А. Сминтина. Одесса : Астропринт, 2000. 226 с.

13. Карпухин П. П. Факультету технологии органических веществ 75 лет. Научная сессия, посвященная 75-летию Харьковского политехнического института имени В. И. Ленина : рефераты докладов. 26-28 декабря 1960 года / М-во высш. и сред. спец. образов. УССР. ХПИ им. В. И. Ленина. Отв. за вып. О. А. Маевский, К. Д. Дубовик. Харьков, 1960. С. 181182.

14. Кондуфор Ю. Ю. Введение. Харьков и Харьковская губерния в первой русской революции 19051907 годов : сборник документов и материалов / под ред. Ю. Ю. Кондуфора; сост.: М. А. Авдушева, В. А. Вострикова, Л. В. Гусева и др. Харьков : Харьк. обл. изд-во, 1955. С. 5-37.

15. Королев Ф. К. Роль машиностроительного факультета в подготовке кадров для промышленности и достижении технического прогресса. Научная сессия, посвященная 75-летию Харьковского политехнического института. Харьков, 1960. С. 23-25.
16. Коропецький I. С. Дещо про минуле, недавнє минуле та сучасне української економіки / гол. ред. С. Головко; ред. Ю. Медюк. Київ : Либідь, 1995.237 с.

17. Отзывы о книгах. Журнал министерства народного просвещения. 1913. Новая серия. Ч. XLVI. № 78. C. $85-128$.

18. Отчет о состоянии и деятельности Екатеринославского Горного Института. Известия Екатеринославского Горного Института. 1914. Год 10. Вып. 1. С. 1-87.

19. Предисловие. Развитие общей механики в России и Украине в 2080-е годы ХХ века / отв. ред. А. Ю. Ишлинский. Москва : Наука; Киев : Феникс, 1998. С. 6-7.

20. Путята Т. В. Діяльність видатних механіків на Україні / за ред. А. Д. Коваленка. Київ : Держ. вид-во. техн. л-ри УРСР, 1952. 267 с.

21. Радциг А. Высшее техническое и коммерческое образование в Германии. Москва : Типо-Литография Товарищества И. Н. Кушнаревъ и К, 1906. С 7.

22. Райков Б. Е. На жизненном пути: автобиографические очерки / отв. ред. Н. П. Копанева; прим. А. Г. Абайдулова, В.С.Волков, А. В. Самокиш; вступ. статья К. В. Манойленко. СПб.: Коло, 2011. Т. 1. 842 с.

23. Речь Председателя К.О.И.Р.Т. О. Г. Г. Де-Метца. Торжественное заседание и речи произнесенные при освящении здания Киевского отделения императорского русского технического общества: оттиск из "Записок"К.О.И.Р.Т.О. Киев : Тип. АО "Петр Барский в Киеве". 1914. T. XLIV. № 5-6. С. 4-12.

24. Русаков В. П. Николай Николаевич Шиллер: жизнь и научно-педагогическая деятельность. Исследования по истории физики и механики. Москва : Наука, 2007. С. 37-77.

25. Симинский К. К. О развитии лаборатории для механического испытания материалов (механической лаборатории) при Киевском Политехническом Институте. Известия Киевского Политехнического Института Императора Александра II. 1916. Киев : Тип. Т-ва И. Н. Кушнерев и К, 1917. Кн. 3-4. С. 186-202.

26. Тарасова В. Высшая инженерная школа в России (некоторые аспекты становления и развития) // Alma-mater. Вестник высшей школь. Москва, 2001. № 11. С. 30-34.

27. Харьковский политехнический: ученые и педагоги / Костенко Ю. 
Т. и др. Харьков : Прапор, 1999. 352 с. 28. Dudka T. Problems of formation the tourism-excursion model of education as a component of XIX mid XX century. Scientific issue of knowledge, education, law and management. Lodz : Wydawca Fundacja "Oswiata i Nauka Bez Granic PRO FUTURO", 2016 (czerwiec). № 2 (14). P. 25-35.

\section{REFERENCES}

1. Akademyk D. M. Synczov // Uchën. zap. Xark. un-ta. 1948. T. 24: Zapysky NY'Y' matematyky, mexanyky y Xarkovskogo matematycheskogo obshhestva. T. 19. S. 5-12.

2. Alterzon G. S. Do istoriyi texnichnoyi osvity na Ukrayini / G.S. Alterzon // Narysy $\mathrm{z}$ istoriyi texniky i pryrodoznavstva /AN URSR. UK RNOIPT; Vidp. red. K. K. Xryenov. K.: Vyd-vo AN URSR, 1962. Vyp. 1. S. 92-96.

3. Bogolyubov A. N. Klassycheskaya mexanyka y texnyka XVII-XIX vv. / A. N. Bogolyubov, A. T. Grygoryan // Mexanyka y cyvylyzacya XVII-XIX vv.: Sb. st.; pod. red. A. T. Grygoryana, B. G. Kuzneczova. M. : Nauka, 1979. S. 68-110.

4. Bunge N. A. K voprosu o vusshem texnycheskom obrazovany / N. A. Bunge. K., 1897. Ch. 1. 12 s.

5. Bunge N. A. K voprosu o vыsshem texnycheskom obrazovany. K., 1897. Ch. II. 9 s.

6. Byulleteny Kyevskogo Polytexnycheskogo Obshhestva Ynzhenerov y Agronomov. K.: Typ. A. M. Ponomareva p.u. Y.Y. Vrublevskogo, 1914. № 2. I-II, 1-24, I-XIV s.

7. De-Metcz G.G. Fyzycheskye instytutu y masterskye fyzycheskyu pryborov za granyceyu: Yzvlech. yz zhurn. "Ynzhener" za 1899 g./ G.G. DeMetcz. K.: Lyto-typ. tovaryshh. Y.N. Kushnerev y Kº, v Moskve, KO, 1900. $66 \mathrm{~s}$.

8. Dragomanov M.P. Lysty na Naddnipryansku Ukrayinu / M.P. Dragomanov // Literaturnopublicystychni praci. K., 1970. T. I. S. 466.

9. Zhurnal Obshhego Sobranya Ymperatorskogo Russkogo Texnycheskogo Obshhestva 31-go yanvarya 1898 goda // Zapysky Ymperatorskogo Russkogo Texnycheskogo Obshhestva. Deyatelnost o-va. SPb.: Typ. Ymper. AN, 1898. № 4. S. 25-31.
10. Y1lyustryrovannuj sbornyk materyalov $\mathrm{k}$ ystory voznyknovenya Kyevskogo Polytexnycheskogo Ynstytuta. Pamyaty Vyktora Lvovycha Kyrpycheva posvyashhaet Kyevskoe Polytexnycheskoe Obshhestvo Ynzhenerov y Agronomov. K.: Typ. Tva Y.N. Kushnerev y Kº 1914. 143 s.

11. IR NBUV: F 41, od. zb. 1651-1665; Ark. 25. Grave D.A.-Bukreevu B.Ya. Pysma 27 fevr. 1901. 22 dekabrya 1935 g.

12. Istoriya Odeskogo universytetu (1865-2000): Naukove vydannya / golovnyj redaktr V. A. Smyntyna. Odessa: Astroprynt, 2000. 226 s.

13. Karpuxyn P. P. Fakultetu texnology organycheskyx veshhestv 75 let / P.P. Karpuxyn // Nauchnaya sessya, posvyashhennaya 75-letyu Xarkovskogo polytexnycheskogo ynstytuta ymeny V. Y. Lenyna. Referat dokladov. 26-28 dekabrya 960 goda / M-vo vussh. y sred. specz. obrazov. USSR. XPY ym. V. Y. Lenyna; Otv. za vыр. O. A. Maevskyj, K. D. Dubovyk. X.: b.y., 1960. S. 181-182.

14. Kondufor Yu. Yu. Vvedenye. Xarkov y Xarkovskaya gubernya $\mathrm{v}$ pervoj russkoj revolyucyy 1905-1907 godov. Sbornyk dokumentov y materyalov; pod red. Yu.Yu. Kondufora; Sost.: M. A. Avdusheva, V. A. Vostrykova, L. V. Guseva y dr. X.: Xak. obl. yzd-vo, 1955. S. 5-37.

15. Korolev F. K. Rol mashynostroytelnogo fakulteta V podgotovke kadrov dlya prombshlennosty y dostyzheny texnycheskogo progressa / F. K. Korolev // Nauchnaya sessy`ya, posvyashhennaya 75-lety yu Xarkovskogo polytexnycheskogo ynstytuta. X., 1960. S. 23-25.

16. Koropeczkyj I. S. Deshho pro mynule, nedavnye mynule ta suchasne ukrayinskoyi ekonomiky / Gol. red. S. Golovko; Red. Yu. Medyuk. K.: Lybid, 1995. $237 \mathrm{~s}$.

17. Otzuvu o knygax // Zhurnal mynysterstva narodnogo prosveshhenya. 1913. Novaya serya. Ch. XLVI. № 7-8. S. 85-128.

18. Otchet o sostoyany y deyatelnosty Ekaterynoslavskogo Gornogo Ynstytuta // Yzvestya Ekaterynoslavskogo Gornogo Ynstytuta. 1914. God 10. Vыр. 1. S. 1-87.

19. Predyslovye // Razvytye obshhej mexanyky v Rossy y Ukrayne v 20-80-e godu XX veka / Otv. red. A.Yu. Yshlynskyj. M. : Nauka; Kyev: Fenyks,
1998. S. 6-7.

20. Putyata T. V. Diyalnist vydatnyx mexanikiv na Ukrayini ; za red. A. D. Kovalenka. K.: Derzh. vyd-vo. texn. 1-ry` URSR, 1952. $267 \mathrm{~s}$.

21. Radcyg A. Vusshee texnycheskoe y kommercheskoe obrazovanye v Germany / A. Radcyg. M.: Typo-Lytografya Tovaryshhestva Y. N. Kushnarev y K, 1906. S. 7.

22. Rajkov B. E. Na zhyznennom puty: avtobyografychesky`e ocherky / otv. red. N. P. Kopaneva; prym. A. G. Abajdulova, V. S. Volkov, A. V. Samokysh; vstup. statya K. V. Manojlenko. SPb.: Kolo, 2011. T. $1.842 \mathrm{~s}$.

23. Rech Predsedatelya K.O.Y.R.T.O. G.G. De-Metcza // Torzhestvennoe zasedanye y rechy proyznesennue pry osvyashheny zdanya Kyevskogo otdelenya ymperatorskogo russkogo texnycheskogo obshhestva: Ottysk yz "Zapysok" K.O.Y`.R.T.O. K.: Typ. AO "Petr Barskyj v Kyeve", 1914. T. XLIV. № 5-6. S. 4-12.

24. Rusakov V. P. Nykolaj Nykolaevych Shyller: zhyzn y n a u c h n o-peda g o g y c hes k a y a deyatelnost / V.P. Rusakov. Yssledovanya po istory y fyzyky i mexanyky. M. : Nauka, 2007. S. 37-77.

25. Symynskyj K. K. O razvyty y laboratory dlya mexanycheskogo ysputanya materyalov (mexanycheskoj laboratory) pry Kyevskom Polytexnycheskom Instytute / K.K. Symynskyj // Izvestya Kyevskogo Polytexnycheskogo Instytuta Imperatora Aleksandra II. 1916. K. : Typ. T-va Y.N. Kushnerev y K, 1917. Kn. 3-4. S. 186-202.

26. Tarasova V. Vusshaya ynzhenernaya shkola v Rossy (nekotorue aspektu stanovlenya y razvytya). Alma-mater. Vestnyk vusshej shkolu. M., 2001. № 11. S. 30-34.

27. $\mathrm{X}$ a polytexnycheskyj: uchene y pedagogy / Kostenko Yu. T. y dr. X. : Prapor, 1999. $352 \mathrm{~s}$.

28. Dudka T. Problems of formation the tourism-excursion model of education as a component of XIX mid XX century. T. Dudka // Scientific issue of knowledge, education, law and management. Lodz : Wydawca Fundacja "Oswiata i Nauka Bez Granic PRO FUTURO", 2016 (czerwiec). № 2 (14). P. 25-35.

Стаття надійшла 22.04.2019 p. 